\title{
Understanding why edema in salvaged myocardium is difficult to detect by late gadolinium enhancement
}

\author{
Martin Ugander ${ }^{1,2^{*}}$, Paul S Bagi ${ }^{1}$, Julian O Booker ${ }^{1}$, Li-Yueh Hsu' ${ }^{1}$, Abiola J Oki ${ }^{1}$, Andreas Greiser ${ }^{3}$, Peter Kellman ${ }^{1}$, \\ Anthony $\mathrm{H}_{\text {Aletras }}{ }^{1}$, Andrew E Arai $^{1}$
}

From 15th Annual SCMR Scientific Sessions

Orlando, FL, USA. 2-5 February 2012

\section{Background}

T2-weighted cardiac magnetic resonance (CMR) can visualize myocardial edema in salvaged myocardium which appears non-infarcted by late gadolinium enhancement (LGE) CMR. However, the mechanisms governing why LGE does not visualize edema in noninfarcted myocardium remain unclear. The objective of the study was to evaluate the extracellular volume fraction (ECV) of edematous salvaged myocardium using quantitative T1-mapping techniques in order to better understand why this tissue may be difficult to detect by LGE imaging.

\section{Methods}

Dogs $(\mathrm{n}=10)$ underwent coronary occlusion and reperfusion, followed by $1.5 \mathrm{~T}$ CMR. Salvaged myocardium was defined as having bright signal intensity on T2-prepared steady-state free precession (T2-prep) images and the absence of infarction by LGE, and signal intensities were quantified SD units brighter than remote myocardium. Myocardial extracellular volume fraction (ECV) was measured by $\mathrm{T} 1$ quantification before and after GdDTPA contrast administration and calibration by blood hematocrit.

\section{Results}

LGE signal intensity of salvaged and infarcted myocardium were $1.7 \pm 0.4$ and $8.1 \pm 1.5$ SD from remote, respectively. T2-prep signal intensity of salvaged and infarcted myocardium were $2.8 \pm 0.2$ and $4.9 \pm 1.0$ SD from remote, respectively. Compared to remote myocardium, T1 of

${ }^{1}$ National Heart, Lung and Blood Institute, National Institutes of Health, Bethesda, MD, USA

Full list of author information is available at the end of the article salvaged myocardium was $14 \%$ higher before contrast $(1050 \pm 114 \mathrm{~ms}$ vs $919 \pm 66 \mathrm{~ms}, \mathrm{p}<0.001)$ and $10 \%$ lower 30 minutes after contrast $(461 \pm 57 \mathrm{~ms}$ vs $512 \pm 67 \mathrm{~ms}$, $\mathrm{p}<0.001)$. The ECV of salvaged myocardium was 34 $+/-7 \%$ which was significantly different than ECV of normal myocardium $24+/-3 \%(\mathrm{p}=0.04)$.

\section{Conclusions}

Salvaged myocardium has a post-contrast T1 which is approximately $50 \mathrm{~ms}$ less than remote myocardium and has an LGE image intensity less than 2 SD from remote, making it difficult to appreciate in LGE images. However, contrast concentration, and thus extracellular space, is determined by the change in $1 / \mathrm{T} 1$ (R1) which occurs from pre- to post-contrast. The combined and directionally opposed differences in pre- and post-contrast T1 explain why the extracellular volume fraction of salvaged myocardium is increased compared to remote. LGE image intensity does not incorporate information on pre-contrast $\mathrm{T} 1$, thus giving the impression of no change in the size of the extracellular space of salvaged myocardium despite the presence of extracellular edema.

\section{Funding}

This work was supported by the Intramural Research Program of the National Heart, Lung, and Blood Institute, National Institutes of Health, USA [1 Z01 HL004607-08 CE].

\footnotetext{
Author details

${ }^{1}$ National Heart, Lung and Blood Institute, National Institutes of Health, Bethesda, MD, USA. '2Dept of Clinical Physiology, Karolinska Institute, Stockholm, Sweden. ${ }^{3}$ Siemens AG Healthcare Sector, Erlangen, Germany.

Published: 1 February 2012
} 


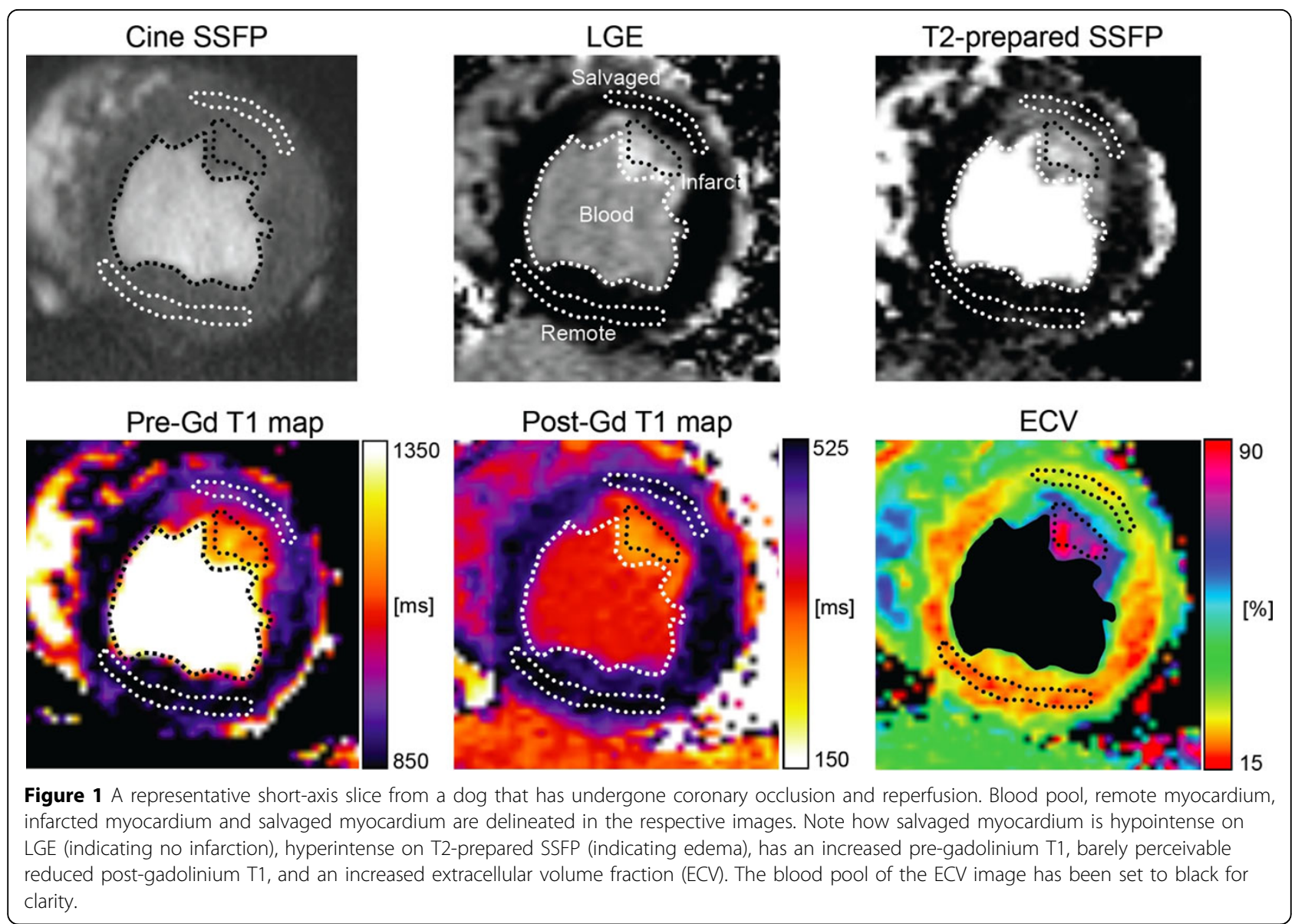

doi:10.1186/1532-429X-14-S1-063

Cite this article as: Ugander et al.: Understanding why edema in salvaged myocardium is difficult to detect by late gadolinium enhancement. Journal of Cardiovascular Magnetic Resonance 201214 (Suppl 1):063.

Submit your next manuscript to BioMed Central and take full advantage of:

- Convenient online submission

- Thorough peer review

- No space constraints or color figure charges

- Immediate publication on acceptance

- Inclusion in PubMed, CAS, Scopus and Google Scholar

- Research which is freely available for redistribution 